\title{
Detection of the extended spectrum $\beta$-lactamase produced by Escherichia coli from dairy cows by using the Vitek-2 method in Tulungagung regency, Indonesia
}

\author{
A.R. Putra ${ }^{1}$, M.H. Effendi ${ }^{2}$, S. Koesdarto ${ }^{3}$, S. Suwarno ${ }^{4}$, \\ W. Tyasningsih ${ }^{5}$ and A.T. Estoepangestie ${ }^{6}$ \\ ${ }^{1}$ Postgraduate Program on Veterinary Public Health, ${ }^{2,6}$ Department of Veterinary Public Health, ${ }^{3}$ Department of Veterinary \\ Parasitology, ${ }^{4,5}$ Department of Veterinary Microbiology, Faculty of Veterinary Medicine, Airlangga University, Surabaya, \\ Indonesia, Email: ${ }^{1}$ akyunrozaqis@gmail.com, ${ }^{2}$ mheffendi@yahoo.com, ${ }^{3}$ skoesdarto@yahoo.com, ${ }^{4}$ snow_arno@yahoo.co.id, \\ ${ }^{5}$ witya_kh@yahoo.com, ${ }^{6}$ soelih.estoepangestie@gmail.com
}

(Received May 15, 2019; Accepted July 10, 2019)

\begin{abstract}
The use of antibiotics in inappropriate on food producing animals can lead to resistance many of the pathogenic bacteria to the various types of antibiotics, one of which is the Escherichia coli (E. coli) which produces extended spectrum $\beta$-lactamase (ESBL). Antibiotic resistance in animals and humans has become a global problem that needs attention and immediate management by using specific antibiotics that used for therapeutic the infected animals. The aim of this study was to isolate and detect E. coli producing ESBL. All E. coli from the surface of dairy cow rectal swabs in Sendang District, Tulungagung Regency, Indonesia using the Vitek-2 method. The number of rectal swab samples used in the present study was 50 . The results of this study showed that all the samples were suspected of being E. coli, based on the morphological growth of colonies on the EMBA media. The isolates were identified by using the biochemical tests. All the samples were positive. In this study the double disc synergy test (DDST) method was using to confirm the ESBL. The antibiotics were used amoxicylyn-clavulanate, ceftazidime and cefotaxime for DDST. In additional ESBL confirmation test was used the Vitek-2 method. The presence of ESBL producing by $E$. coli isolated from rectal dairy swabs in tulungagung was $6 \%(3 / 50)$.
\end{abstract}

Keywords: E. coli, ESBL, Vitek-2, Dairy Cows

Available online at http://www.vetmedmosul.com, (C) 2020, College of Veterinary Medicine, University of Mosul.

This is an open access article under the CC BY 4.0 license (http://creativecommons.org/licenses/by/4.0/).

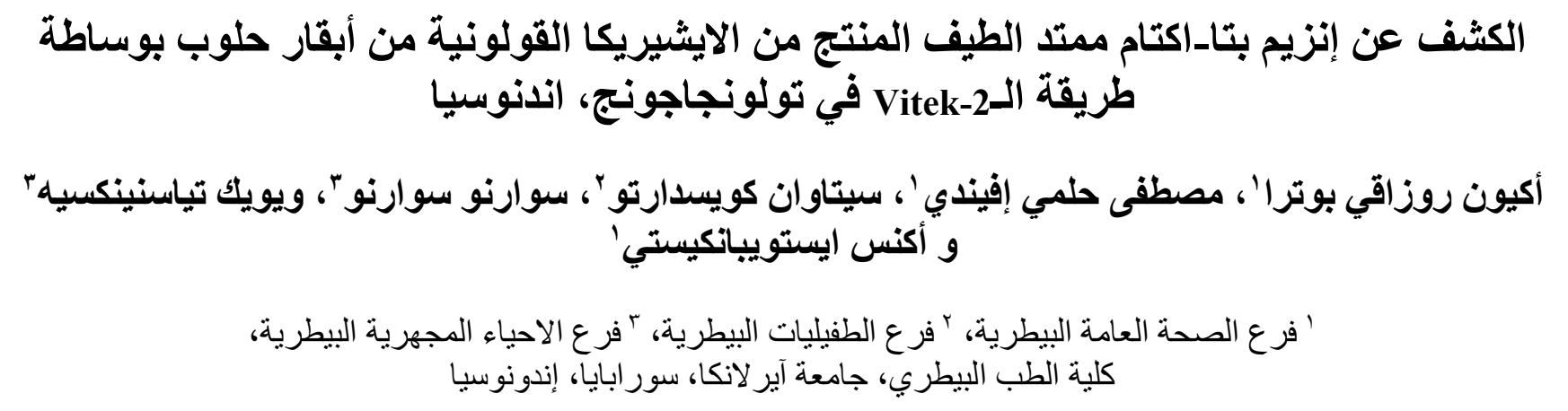

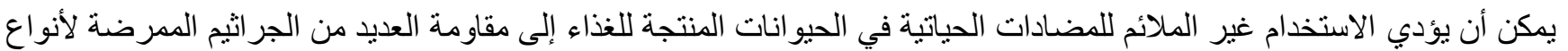

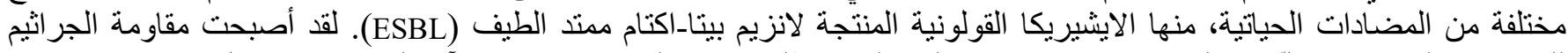
للمضادات الحياتية في كلٍ من الحيو انات والإنسان مشكلة عالمية تتطلب الانتباه لها و إجر اء تدابير آنية لتفاديها من خلال استخدام مضادات 


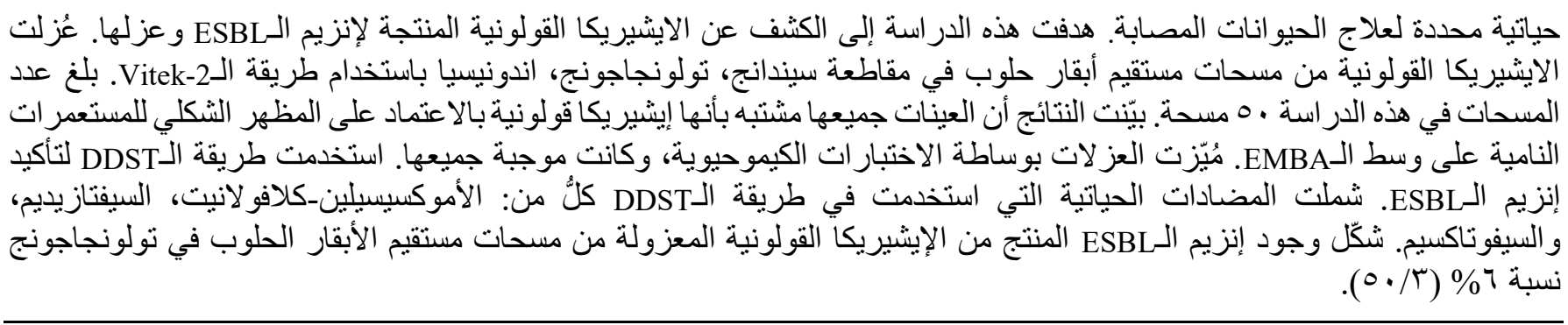

\section{Introduction}

The occurrence of antibiotic resistance is caused by the excessive and inaccurate use of antibiotics in the treatment. The Bacteria show the resistance to the antibiotics when their growth cannot be inhibited by using the antibiotics at the maximum doses. The development of the resistance of the microorganisms to antibiotics is a consequence of the wrong use of antibiotics. The bacteria resistance to antibiotics is due to occur the mutation or resistance of the gene to specific antibiotics. The antibiotic resistance is currently a public health problem and has been reported by the WHO that the antibiotic resistance poses a threat to human health (1). The bacteria resistance to antibiotics have a different mechanism, one of them is through a gene transfer via a plasmid. The gene responsible for the production of $\beta$-lactamase is located in a plasmid or chromosome of the most important enzymes carried by plasmids. The bacteria that produce the betalactamase enzyme can be called the bacterium ESBL. The ESBL is an enzyme which has the ability to hydrolyze first, second, and third generation cephalosporin antibiotics, and aztreonam groups. Carbapenem is not inhibited by betalactamase inhibitors such as clavulanate, sulbactam and tazobactam (2). The resistence caused by ESBL bacteria is often associated with resistance to other antibiotics used in humans (1). The infected animals play an important role to spread bacteria resistant to antibiotics by contaminating the farms through the feces, slaughterhouses, and workers which are direct contact with the infected animals. In addition, The animals may be exposed to the contamination by drinking the water contains the bacteria resistant to antibiotic (3). The pets at home play an important role to infect the human with bacteria resistant to antibiotics, especially the animals which are closely related to human life (4). Many of the studies showed There is similar of the ESBL producing E. coli which isolated in humans, livestock, wildlife (5).

The aims of the study are to isolate and detect the presence of ESBL producing E. coli through its resistance to $\beta$-lactam antibiotics using the Vitek-2 method. This method is very superior for detecting betalactam enzymes. The method of Vitek-2 is regarded as an automatic identification system for microorganisms to show the phenotype of the isolates tested and able to determine the sensitivity or resistance of an isolate to antibiotics (6).

\section{Materials and methods}

\section{Sampling method}

The rectal swab samples were taken from November 2018 to March 2019 from dairy farms in Sendang district, Tulungagung regency. The number of samples taken from rectal swab samples in dairy cows was 50 . The swab results are labeled and all the samples must be aseptic by using a sterile stick swab then put it in an eppendeorf tube containing $1 \%$ pepton water buffer media. All the samples are stored in the ice box and immediately ttransport to the laboratory for inspection (7).

\section{Isolation and identification of $\boldsymbol{E}$. coli}

The swab rectal samples were planted on briliant green bile broth (BGBB) media (Merck, Darmstadt, Germany). All the samples were incubated at $37^{\circ} \mathrm{C}$ for $18-24$ hours (8). The positive results are indicated by the presence of gas bubbles in the durham tube and green changes to cloudy green. After being positive, the $E$. coli isolates were planted in eosin methylene blue (EMBA) media (Merck, Darmstadt, Germany) by streaking and incubating at $37^{\circ} \mathrm{C}$ for 24 hours. The suspect colonies of $E$. coli on EMBA media are metallic green. The colonies of E. coli grown in EMBA were planted again in $1 \%$ pepton water buffer media, then incubated at 37 ${ }^{\circ} \mathrm{C}$ for 24 hours. The incubated pepton water media is dripped with Kovach reagents in two or three drops. A positive result for $E$. coli is indicated by the formation of a red ring on the surface of the media at $1 \%$ pepton water buffer. Furthermore, the positive isolates of $E$. coli were planted on EMBA and incubated at $37^{\circ} \mathrm{C}$ for 24 hours (9).

\section{ESBL confirmation: Double Disk Synergy Test (DDST)}

The E. coli ESBL confirmation test was carried out by using DDST method which produced a qualitative category with sensitive, intermediate and resistant assessment using an antibiotic disk (OXOID, Basingstoke, United Kingdom) amoxycilin-clavulanate $30 \mu \mathrm{g}(\mathrm{CT} 0223 \mathrm{~B})$, cefotaxime $30 \mu \mathrm{g}$ (CT0166), ceftazidime $30 \mu \mathrm{g}$ (CT0412). Planting on the plate to be carried out by taking the E. coli isolates in the standard turbidity test Mc Farland 0.5 was then gently rubbed with a sterile swab on the entire surface of the mueller hinton agar (MHA) media. Interpretation of results by measuring the inhibition of the diameter of the inhibitory 
zone formed in accordance with the Clinical and Laboratory Standards Institutions (CLSI) (10).

\section{Vitek-2 Compact}

All the resistance category of the E. coli isolates were tested for the phenotype identification and confirmation using the Vitek-2 compact system method and worked according to the protocol (BioMerieux, Marcy L'Eyoily, France). The results automatically came out in the form of a pint out.

\section{Results}

The result of this study showed that all the E.coli isolated from the rectal dairy were positive $100 \%$. All the E. coli showed a change in bright green to cloudy green and gas in the durham tube on BGBB media. In the EMBA media all the isolates showed a change in color to metallic green. There is a red ring on the pepton water buffer media when added with the kovach reagent in the pepton water buffer media as many as 50 positive samples of $E$. coli. The positive isolates of $E$. coli were purified by eosin methylene blue agar (EMBA) media which appeared metallic green (Figure 1).

The ESBL confirmation test of the E. coli isolates using DDST and VItek-2 methods. In this method there were three positive samples of ESBL 6\% (Table 1). In the DDST method there is an enlargement zone with the synergy pattern of the three antibiotics with amoxycylin-clavulanate as its inhibitor (Figure 2).

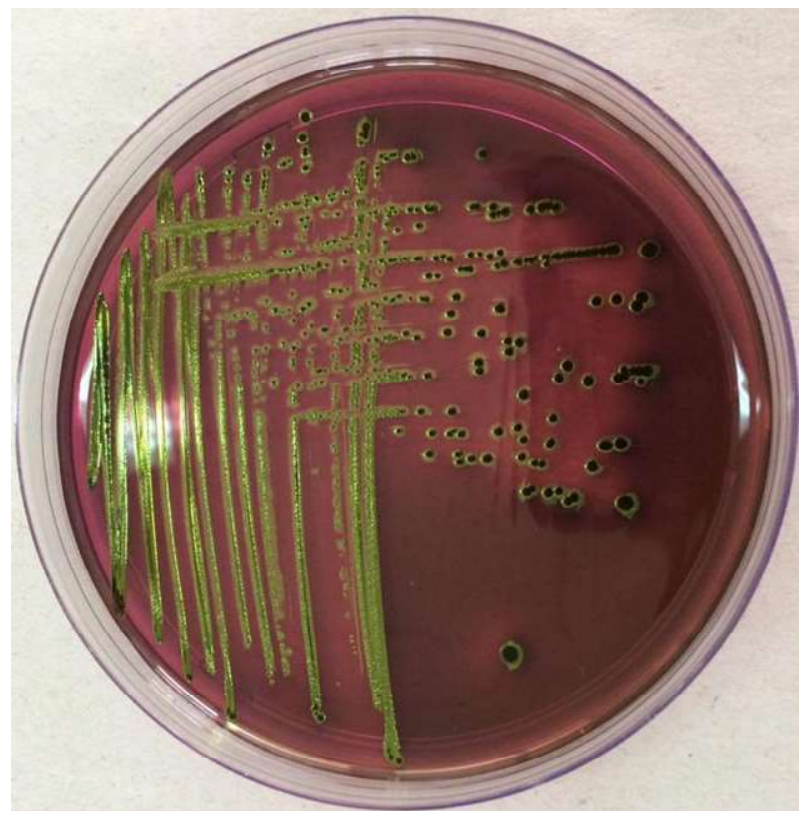

Figure 1: Presumtive E. coli in EMBA media with the metallic green color.

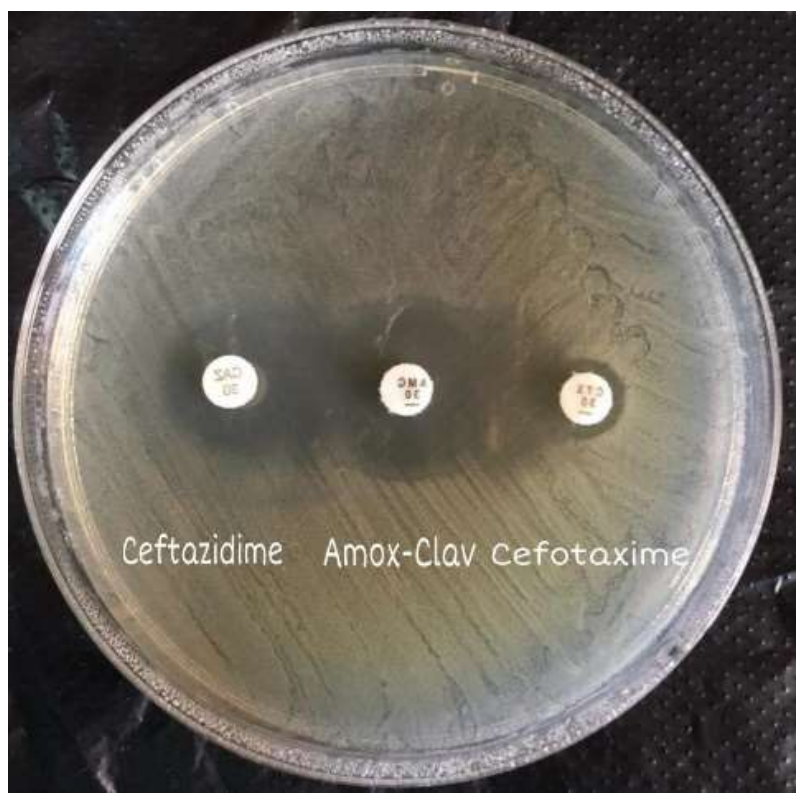

Figure 2: The double disc synergy test for ESBL confirmation.

Table 1: Data of the E. coli isolates in this study from Tulungagung farms

\begin{tabular}{ll}
\hline Location & Tulungagung regency \\
\hline No. samples & 50 \\
Positive E. coli & 50 \\
\hline ESBL Confirmation by DDST & 3 \\
ESBL Confirmation by Vitek-2 & 3 \\
\hline
\end{tabular}

\section{Discussion}

The infected animals that have closely related to the human that becomes the main reservoir to the spread of bacteria resistant to an antibiotic in the environment and infected the human (11). O'brien (12) said that E. coli plays a role in the spread of genes resistant to bacterial populations between animals and humans through foodborne.

Screening of ESBL producing bacteria is usually done in humans only and in the hospital environment, but there are many studies show that the emergence of pathogenic bacteria had found in the livestock and animal food (13). The presence of ESBL producing Enterobacteriaceae bacteria in the feces samples which taken of livestock may raise the risk of carcass contamination at the time of cutting in the slaughterhouse, thus lead to potentially contaminating meat products (14). ESBL producing Enterobacteriaceae, including E. coli, which contaminate products of animal origin have the potential to cause health risks even though the level of risk is difficult to quantify (15). The ESBL pengsssil infection through food consumption from animal 
origin can cause limited choices in handling patients. This situation can extend the period of treatment, increase the cost of treatment, increase the incidence of disease, and the death (16).

Many of research reported on cases of ESBL producing $E$. coli in animals have been widely carried out in the various countries. Babypedmini and Appalaraju (17) showed that ESBL producing E. coli was $41 \%$ and $K$. pneumonia was $40 \%$. The prevalence of ESBL producing E. coli in Malaysia was $5.6 \%$, Japan $8.1 \%$, Philippines $13.3 \%$, Taiwan $16.7 \%$ and Indonesia $23 \%$ (18). The prevalence of ESBL producing E. coli from beef feces in Bogor, Indonesia was 15.8\% (19). In addition, Haenni et al. (20) showed that the prevalence of ESBL producing $E$. coli from 491 calf stools isolated from 12 slaughterhouses $29.4 \%$.

Schmid et al. (21) reported that the ESBL producing $E$. coli contamination originating from samples of dairy and beef cattle farms taken from 2011-2012 in Bavaria, Germany was 32,8 \%. In another study Sabrina et al. (22) obtained a higher yield of the incidence of ESBL producing E. coli contamination originating from dairy farms in Germany was $75,6 \%$. Many of research conducted in Indonesia regarding the level of contamination of ESBL producing bacteria is still focused on contamination which occurs in humans. The incidence of ESBL producing bacterial infections in the hospitals in Surabaya from 2006-2012, namely 34.84\% (23), $6.7 \%$ (24), and $94.5 \%(25)$.

According to CLSI (26) explained that the Vitek-2 compact system tool is a system for identifying and testing semi-automatic resistance for bacteria making it possible to determine MIC rapidly by analyzing the kinetics of bacterial growth with antimicrobials using a card to test. This Vitek-2 method has proven to be very good at detection bacterial resistance to an antibiotic because the results are very accurate (27). In a study conducted by Spanu et al. (28) showed that the Vitek-2 method has a sensitivity of $98.1 \%$ and a specificity of $99.5 \%$. The compact serinng vitek-2 method is used as a reference in detecting ESBL producing Enterobacteriaceae and this method from several references and studies is highly recommended to identify ESBL producing bacteria using this method.

\section{Conclusion}

The detection of ESBL producing $E$. coli from dairy farms in Tulungagung Regency was $3(6 \%)$ for confirmation using DDST and Vitek-2. These results indicate that ESBL producing $E$. coli can threaten animal and human health which can spread quickly and widely. The results of this study indicate that the high prevalence of ESBL producing E. coli on Sendang, Tulungagung Regency, Indonesia.

\section{Acknowledgements}

This study was supported in part with Hibah Mandat, Fund Airlangga University, Indonesia.

\section{References}

1. WHO. Critically important antimicrobials for human medicine. $5^{\text {th }}$ ed. Geneva; WHO Press; 2016. 1-2 p.

2. Paterson DL, Bonomo RA. Extended-spectrum beta-lactamases: A clinical update. Clin Microbiol Rev. 2005;18(4):657-686. doi: 10.1128/CMR.18. 4.657-686.2005

3. Price LB, Graham JP, Lackey LG, Roess A, Vailes R, Silbergeld E. Elevated risk of carrying gentamicin-resistant Escherichia coli among US Puoltry workers. Environ Health Perspect. 2007;115(12):17381742. doi: 10.1289/ehp. 10191

4. Guerra B, Fischer J, Helmuth R. An emerging public health problem: acquired aarbapenemase-producing microorganisms are present in food-producing animals, their environment, companion animals and wild birds. Vet Microbiol. 2014;171(3-4):290-297. doi: 10.1016/ j.vetmic.2014.02.001

5. Hordijk J, Schoormans A, Kwakernaak M, Duim B, Broens E, Dierikx C, Dik M, Jaap AW. High prevalence of fecal carriage of extended spectrum ß-lactamase/AmpC-producing Enterobacteriaceae in cats and dogs. Front Microbiol. 2013;4 :274. Doi: $10.3389 /$ fmicb. 2013.00242

6. Sanders A, Amanda M. Vitek 2 compact-identification and susceptibility testing. USA: Standard Operating Procedure; 2018. 4-24 p.

7. Safitri RD, Cicilia R, Bintari IG, Hermawan IP, Effendi MH, Ernawati $\mathrm{R}$, Rahmahani J. Detection of encoding gene extended spectrum beta lactamase on Escherichia coli isolated from broiler chicken meat in traditional market Surabaya. Inter J Develop Res. 2017;07(11):1725417357. ISSN : 2230-9926.

8. Effendi MH, Harijani N, Yanestria SM, Hastutiek P. Identification of shiga toxin-producing Escherichia coli in raw milk samples from dairy cows in Surabaya, Indonesia. Philippine J Ved Med. 2018;55(SI):109114.

9. Effendi MH, Harijani N, Budiarto, Triningtya NP, Tyasningsih W, Plumeriastusi H. Prevalensi of pathogenic Escherichia coli isolated from subclinical mastitis in east Java province, Indonesia. Indian Vet J. 2019;96(03):22-25.

10. CSLI. Performances standards for antimicrobial susceptibility testing. $26^{\text {th }}$ ed. New York: Clinical and Laboratory Standards Institute; 2016. 1-34 p.

11. Santos LL, Moura RA, Agilar-Ramires P, Castro AP, Lincopan N. Current status of extended-spectrum $\beta$-laktamase (ESBL)-producing Enterobacteriaceae in animals. $1^{\text {st }}$ ed. USA: Formatex; 2013. 1600-1607 p.

12. O'Brien TF. Emergence, spread, and environmental effect of antimicrobial resistance: how use of an antimicrobial anywhere can increase resistance to any antimicrobial anywhere else. Clin Infect Dis. 2002;3:78-84. doi: 10.1086/340244

13. Ghatak S, Singha A, Sen A, Guha C, Ahuja A, Bhattacharjee U, Das S, Pradhan NR, Puro K, Jana C. Detection of New Delhi metallobetalactamase and extended spectrum beta-lactamase genes in Escherichia coli isolated from mastitic milk samples. Transbound Emerg Dis. 2013;60(5):385-9. doi: 10. 1111/tbed.12119

14. Geser N, Stephan R, Kuhnert P, Zbinden R, Kaeppeli U, Cernela N, Haechler H. Fecal carriage of extended-spectrum $\beta$-laktamaseproducing Enterobacteriaceae in swine and cattle at slaughter in Switzerland. J Food Protect. 2011;74(3):446-449. doi: 10.4315/0362028X.JFP-10-372

15. EFSA. Scientific opinion on the public health risks of bacterial strains producing extended-spectrum $\beta$-lactamases and/or AmpC $\beta$-lactamase 
in food and food-producing animals. EFSA J. 2011;9(8):1-95. doi: 10.2903/j.efsa.2011.2322

16. Khosbayar T, Munguntsetseg B, Ochbadrakh B, Udval U, Batbaatar G, $\mathrm{Wu}$ J, Yong D. Plasmid analysis of ESBL producing gram negative bacilli in Mongolia. Mongolian J Hea Sci. 2013;10(1):90-100.

17. Babypedmini S, Appalaraju B. Extended spectrum $\beta$-lactamases in urinary isolates of Escherichia coli and Klebsiella pneumonia prevalence and susceptibility pattern in a tertiary care hospital. Indian J Med Microbiol. 2004;22(3):172-4.

18. Parasakthi N, Arrifin H, Kamarulzaman A, Ibrahim HSM, Adnan A, Choeng I. Consensus guidelines for the management of infections by ESBLproducing bacteria. Malaysian Soc Infect Dis Chemother. 2001;7:3.

19. Sukmawinata E. Tingkat kejadian Escherichia coli penghasil extended spectrum $\beta$-lactamase di feses sapi di rumah potong hewan ruminansia kota Bogor [MSc thesis]. Bogor: Institut Pertanian Bogor; 2015. 1-185 p.

20. Haenni M, Châtre P, Métayer V, Bour M, Signol E, Madec JY, Gay E. Comparative prevalence and characterization of ESBL producing Enterobacteriaceae in dominant versus subdominant enteric flora in veal calves at slaughterhouse, France. Vet Microbiol. 2014;171:321327. doi: $10.1016 /$ j.vetmic.2014.02.023

21. Schmid A, Hörmansdorfer S, Messelhäusser U, Käsbohrer A, SauterLouis C, Mansfeld R. Prevalence of extended-spectrum $\beta$-lactamaseproducing Escherichia coli on Bavarian dairy and beef cattle farms. Appl Environ Microbiol. 2013;79(9):3027-3032. doi: 10.1128/AEM.00204-13

22. Odenthal S, Akinenden O, Usleber E. Extended-Spectrum $\beta$-Lactamase producing Enterobacteriaceae in bulk tank milk from German diary
Farm. Inter J Food Micribiol. 2016;238:72-78. doi: 10.1016/j.ijfoodmicro.2016.08.036

23. Kuntaman, Mertiasih NM, Hadi U. Multiresistance pattern of extended spectrum $\beta$-lactamase (ESBL)-Escherichia coli and Klebsiella pneumoniae strains. Folia Med Indones. 2006;42(1):40-46.

24. Bramantono PH. The prevalence of extended spectrum betalactamase (ESBL) in third generation cephalosporin usage among sepsis patients in the department of internal medicine RSUD Dr Soetomo Surabaya. Folia Med Indones. 2012;49(4):244-251.

25. Severin JA, Mertaniasih NM, Kuntaman K, Lestari ES, Purwanto M, Toom NL, Duerink DO, Hadi U, Belkum A, Verburg HA, Goessens WH. Molecular characterization of extended-spectrum $\beta$-lactamases in clinical Escherichia coli and Klebsiella pneumoniae isolates from Surabaya, Indonesia. J Antimicrob Chemother. 2010;65:465-469. doi:10.1093/jac/dkp471

26. CLSI. Performance standards for antimicrobial susceptibility testing. $24^{\text {th }}$ ed. Pennsylvania: Clinical Laboratory and Standard Institute; 2014. $1-25$.

27. Munoz-Davila MJ, Roig M, Yague G, Blazquez A, Salvador C, Segovia M. Comparative evaluation of Vitek-2 identification and sucepbility testing of urinary tract pathogens directly and isolated from chromogenic media. Eur J Clin Microbiol Infect Dis. 2013;32:773-780. doi: 10.1007/s10096-012-1806-4

28. Spanu T, Sanguinetti M, Tumbarello M, D’Inzeo T, Fiori B, Posteraro B, Santangelo R, Cauda R, Fadda G. Evaluation of the new VITEK-2 Extended-Spectrum Beta-Lactamase (ESBL) test for rapid detection of ESBL production in Enterobacteriaceae isolates $\mathrm{J}$ Clin Microbiol. 2006;44(9):3257-3262. doi: 10.1128/JCM.00433-06 